\title{
Soft Tissue Sarcoma, Excluding Liposarcoma
}

National Cancer Institute

\section{Source}

National Cancer Institute. Soft Tissue Sarcoma, Excluding Liposarcoma. NCI Thesaurus.

Code C153361.

A finding indicating the presence of a sarcoma arising from the soft tissue, other than liposarcoma. 